\title{
Airborne Staphylococcus aureus in different environments-a review
}

\author{
Anna Kozajda ${ }^{1}$ (1) $\cdot$ Karolina Jeżak $^{1} \cdot$ Agnieszka Kapsa $^{1}$
}

Received: 21 February 2019 / Accepted: 23 September 2019 / Published online: 25 October 2019

(C) The Author(s) 2019

\begin{abstract}
The aim of the literature review was to describe the environments where the presence of airborne Staphylococcus aureus was confirmed and to catalogue the most often used methods and conditions of bioaerosol sampling to identify the bacteria. The basis for searching of studies on $S$. aureus in the bioaerosol in different environments was PubMed database resources from the years 1990-2019 (May). The review included studies which were carried on in selected environments: hospitals and other health care facilities, large-scale animal breeding, wastewater treatment plants, residential areas, educational institutions, and other public places. The highest concentrations and genetic diversity of identified $S$. aureus strains, including MRSA (methicillin-resistant $S$. aureus), have been shown in large-scale animal breeding. The role of the airborne transmission in dissemination of infection caused by these pathogens is empirically confirmed in environmental studies. Commonly available, well-described, and relatively inexpensive methods of sampling, identification, and subtyping guarantee a high reliability of results and allow to obtain fast and verifiable outcomes in environmental studies on air transmission routes of $S$. aureus strains.
\end{abstract}

Keywords S. aureus $\cdot$ MRSA $\cdot$ Bioaerosol $\cdot$ Indoor air · antibiotic resistance $\cdot$ Occupational exposure

\section{Introduction}

Although the public health problem related to pathogenic bacteria of Staphylococcus aureus species is not new (Duckworth and Jordens 1990; Lowy 1998), yet in the last decade, year after year, more and more scientific alarms and reports about the increasing epidemiological risk have been coming from all continents (Agostino et al. 2017; Chang and Lin 2018; Denis 2017), especially in the context of acquiring by this species the genes of antibiotics resistance (Arias and Murray 2015; Epstein et al. 2016; Nadimpalli et al. 2018; Spellberg et al. 2008; Tacconelli et al. 2018). It has been estimated that complications in treatment refer, depending on the source, to 11$53 \%$ of S. aureus bacteremia (Keynan and Rubinstein 2013).

S. aureus is both a commensal (it colonizes nostrils, 20$40 \%$ of the general population are carriers) and a pathogen

Responsible editor: Diane Purchase

Anna Kozajda

anna.kozajda@imp.lodz.pl

1 Nofer Institute of Occupational Medicine, 8 Teresy Str, 91-348 Łódź, Poland (causing mainly opportunistic infections of soft tissues, skin, and wounds, but also infections of blood, osteomyelitis, septic arthritis, endocarditis, pneumonia, and sepsis) (Gordon and Lowy 2008; Frank et al. 2010; Keynan and Rubinstein 2013; Nadimpalli et al. 2018; Otto 2010). S. aureus exhibits a number of properties which cause their high invasiveness (synthesis of enzymes which induce cytolytic effects, toxins which induce an inflammatory effect, and exotoxins causing the toxic shock syndrome and surface proteins, binding with cells, proteins, and blood cells in the attacked organism) (Gordon and Lowy 2008) and recurrent infections (formation of endospores and biofilms) (Conlon 2014). Furthermore, the S. aureus species is known for its easy acquisition of the genes of resistance to antibiotics (Chen 2013), especially from the group of $\beta$-lactams - methicillin-resistant $S$. aureus (MRSA) (Becker et al. 2014), but also to drugs from other groups of antibiotics (Long et al. 2006).

S. aureus exhibits many features which cause a high virulence and consequently also a high invasiveness (Gordon and Lowy 2008; Foster 2005). Considered as the most important virulence factors are the surface proteins described as microbial surface components recognizing adhesive matrix molecules, MSCRAMM (Foster and Hook 1998; Patti et al. 1994). These proteins bind the particles of collagen, fibronectin, and 
fibrinogen on the tissues of attacked organism (adherence to host tissue); therefore, they closely adhere to them and induce infections, including intravascular infections, those of bones, joints, or prosthetic-device infections (Gordon and Lowy 2008). Other factors of virulence comprise the formation of biofilms and endospores (Conlon 2014) and production of enzymes which induce the cytolytic effect, e.g. proteases, lipases, and evading or destroying of the host protection, e.g. leukocidins (Gordon and Lowy 2008; Foster 2005; Foster 2009). Other virulence factors include the following: cluster of genes called arginine catabolic mobile element (ACME), coagulase, or lactoferrine (Baba et al. 2002; Foster 2009; Gordon and Lowy 2008; Sollid et al. 2014).

Some strains of $S$. aureus are capable of producing specific immunomodulatory toxins which exhibit stimulating and mitogenic effects towards $\mathrm{T}$ lymphocytes, which may induce the collapse and toxic shock syndrome, including shock syndrome toxin-1 (TSST-1) (Sergelidis and Angelidis 2017). These toxins cause food poisoning (Denayer et al. 2017; Hennekinne et al. 2012; Sharma et al. 2018).

However, the most serious problem is that this species easily acquires resistance to many antibiotics simultaneously (multiantibiotics resistance), especially in the case of methicillin-resistant $S$. aureus (MRSA) (Becker et al. 2014; Boyce et al. 2005; Chen 2013; Gould et al. 2012; Paterson et al. 2014). According to the CDC report (2013), MRSA causes a number of diseases, starting from infections of skin and wounds to pneumonia and blood poisoning which may cause sepsis and death (Agostino et al. 2017; Daum 2007; David et al. 2014; Toro et al. 2014). Originally, MRSA constituted the main cause of nosocomial infections, but integrated preventive measures undertaken in health care facilities significantly decreased the percentage rate of nosocomial infections by as much as 54\% during 2005-2011. It appeared, however, that the problem did not disappear but reached further than the hospital environment (hospital-associated MRSA, HAMRSA), and in recent years, a continuous increase has been noted in MRSA infections in general population, especially the community-associated MRSA (CA-MRSA) and livestockassociated strains (LA-MRSA) (CDC 2013; Davis et al. 2012; Ferguson et al. 2016; WHO 2018). The epidemiological studies showed that the most common way of transmission of $S$. aureus, both sensitive and antibiotic-resistant strains, is the transfer type human-to-human through healthy animal farm workers (carriers of the bacteria) to their household members (Nadimpalli et al. 2018; Wardyn et al. 2015). The costs associated with treatment of the infection, prolonged hospitalization, and prevention of the spread of $S$. aureus are difficult to estimate, but they are surely very high (in billions of EUR annually) both for the health service, due to the undertaken procedures, and for the entire economy in relation to the absence from work and deaths (Antonanzas et al. 2015; Claus et al. 2014; Köck et al. 2010; Kraker et al. 2011; Lee et al. 2013).
Admittedly, the causes of the infection in humans are usually those strains which had colonized the anterior nares (DeLeo et al. 2010; Frank et al. 2010; von Eiff et al. 2001; Madsen et al. 2018a, b). Angen et al. (2017) showed in the experimental study with the volunteers that increased concentration of airborne MRSA could be an essential factor of the human nasal carriage of those strains. However, the authors conclude that a short-term inhalable exposure to MRSA can result in the nasal carriage, but young and healthy human organism is capable of removing pathogens within a few hours to a few days (Angen et al. 2017).

Therefore, the bacteria are particularly significant in the case of the people exposed environmentally, including hospitals and in such environments where there is a high probability of the occurrence of pathogenic and multiantibiotic-resistant strains, including the municipal wastewater treatment plants (WWTP) (Boopathy 2017; Gordon and Lowy 2008) or animal farms (Friese et al. 2013). The airborne transmission is as significant as the direct transmission of bacteria by the hands or mouth, although it may be difficult to indicate which of those routes is the most important for health care personnel (Bos et al. 2016; Chang and Lin 2018). S. aureus bacteria, similarly to other species from Staphylococci genus, are characterized by a high survival rate in dry environments, e.g. on surfaces or other materials commonly present at homes (Gupta et al. 2017; Kramer et al. 2006). Due to this feature, the settled dust can be a source of $S$. aureus and re-aerolisation of this dust causes an increased risk of bacteria inhalation (Madsen et al. 2018b). The studies prove that pathogenic strains of $S$. aureus are able to survive under unfavourable conditions, on dry surfaces, for a long period, even several months and still can be contagious for exposed humans (Beard-Pegler et al. 1988; Boyce 2007; Duckworth and Jordens 1990; Farrington et al. 1992; Hübner et al. 2011; Kramer et al. 2006). From this point of view, the most important factor associated with the presence and concentration of the $S$. aureus bacteria in the indoor air seems to be the air change rate (ACR), but also other factors such as relative humidity (RH) and season (Madsen et al. 2018b).

Methicillin-resistant Staphylococcus aureus (MRSA) occurs in public places and wastewater treatment plants, but it is most prevalent in hospitals (Agostino et al. 2017; Boopathy 2017; Boyce 2007; Boyce et al. 2005; Börjesson et al. 2010; Conceição et al. 2013; DeLeo et al. 2010; Otter and French 2009; Rosenberg Goldstein et al. 2012; Thompson et al. 2013; Wardyn et al. 2015). The direct sources of MRSA bacteria present in wastewater treatment plants are the wastes coming from hospitals and from the areas where animal husbandry is conducted (Wan and Chou 2014).

The studies carried out at homes confirmed the risk of exposure to airborne $S$. aureus in the residential environment (Gandara et al. 2006; Madsen et al. 2018b; Moon et al. 2014) and in public places (Conceição et al. 2013; Lenar-Boroń et al. 
2014; Li et al. 2015; Lin et al. 2016; Messi et al. 2015; Moritz et al. 2015; Peng et al. 2015; Wlazło et al. 2008; Zhou and Wang 2013). Parrish et al. 2018 in the epidemiological study tried to find any relationship between the CA-MRSA soft tissue infections in children and their visits to public places within 3 months before hospitalization. However, the data analysis did not confirm any cause-and-effect relationship.

The aim of the literature review was to describe the types of environments where the presence of airborne $S$. aureus was confirmed and to catalogue the most often used methods and conditions of bioaerosol sampling to identify the bacteria.

\section{Material and methods}

Investigations of Staphylococcus aureus bacteria presence in the bioaerosol in different environments were eligible for inclusion. The PubMed database was searched with crossing of the following keywords: 'Staphylococcus aureus', 'MRSA', 'LA-MRSA', 'CA-MRSA', 'environment', 'environmental exposure', 'hospital', 'animal husbandry', 'CAFOs', 'WWTP', 'bioaerosol', 'indoor air', and 'air transmission route' during 1990-2019 (May).

\section{Hospital environment}

The hospital environment constitutes the main source and risk in spreading of $S$. aureus bacteria (CDC 2013). Interesting results were obtained by Frìaz-De León et al. (2016) who conducted in two hospitals of Mexico the research aimed at determination of the genera and incidence of airborne bacteria as well as the genetic similarity between environmental Staphylococcus spp. isolates (from the air) and clinical ones (from the patients). In the sampled air, the genus and species identification of isolated pure bacterial cultures was identified, and then, their sensitivity to antibiotics was analysed. It has been demonstrated that in the air of both hospitals, the bacteria of Staphylococcus genus dominated, while $S$. aureus took the fifth place of the total twenty five identified species. In the first hospital, $45 \%$ isolates belonging to Staphylococcus genus exhibited resistance to methicillin, but in the latter institution, none of the isolates was antibiotic resistant. The similarities between clinical and environmental $S$. aureus isolates were analysed using the dendrogram constructed according to the unweighted pair group method with arithmetic averages (UPGMA). The occurrence of three different genotypes was demonstrated. The first genotype is represented by the first group exhibiting $100 \%$ similarity, which comprises 6 clinical isolates of $S$. aureus coming from the patients, and this proves that they were infected with the same clone. The second genotype was identified in the clinical isolate coming from the patient hospitalized in the pulmonological ward, while the third genotype came from Staphylococcus aureus isolates occurring in the environment. These results undermined the hypothesis about the existence of a genetic relation between environmental and clinical strains, although the authors suspect that the probable cause was the too low quantity of analysed samples.

Beggs (2003) reviewed literature with the aim to confirm the role of airborne route in the transmission of nosocomial infections induced by MRSA strains and indicated that although there were strong foundations which in theory show that this route may be significant, yet this has not been confirmed empirically.

Mirzaei et al. (2014) conducted the research aimed at determination of the quantity and type of bacterial infections in hospitals. Seventy two air samples were collected from 3 operating rooms and from 3 consulting rooms, where 17 genera of bacteria, including Staphylococcus spp., were found. Identification of the species showed that $S$. aureus at a concentration of $12.5 \pm 7.5 \mathrm{CFU} / \mathrm{m}^{3}$ was dominant. Because of possible infections and prolonged wound healing time, the author of the studies suggests the need for monitoring of the concentration and species diversity of bioaerosols present in hospitals, especially in operating rooms.

Nandalal and Somashekar (2007) monitored for 2 years the incidence of Staphylococcus aureus bacteria in the hospital indoor air. The highest concentration of $S$. aureus bacteria, reaching $95 \mathrm{CFU} / \mathrm{m}^{3}$, was shown in the air sample collected in the paediatric ward. In the samples coming from the general ward, the concentrations of samples reaching 50,63, and $75 \mathrm{CFU} / \mathrm{m}^{3}$ were found. In the air sample collected in the operating room, the value of $13 \mathrm{CFU} / \mathrm{m}^{3}$ was indicated; in the delivery room, it was $75 \mathrm{CFU} / \mathrm{m}^{3}$, in the endoscopy room $25 \mathrm{CFU} / \mathrm{m}^{3}$, and in the treatment room $63 \mathrm{CFU} / \mathrm{m}^{3}$. Simultaneously sampled was the outdoor air (control sample, outdoor background of the research), in which no $S$. aureus was identified. The authors concluded that because $S$. aureus occurred in all sampling places, it becomes necessary to monitor microflora in hospitals and undertake appropriate measures to prevent infections induced by airborne pathogens.

The studies on the quality of air and amount of bacteria and fungi in private and governmental public health care centres were conducted by Rangaswamy et al. (2013) with the aim to point out the level of airborne pathogens. The identified bacteria contained $S$. aureus species in different concentrations, depending on the air sampling place and time. In the case of samples collected in a private hospital, the highest concentration of $S$. aureus was identified in the emergency ward, in samples collected in the evening. As to the governmental health care centre, the highest $S$. aureus concentration - as in the case of a private health care centre - was identified in air samples collected in the evening and coming from the emergency ward. A high concentration was found in samples collected both in the morning and in the evening in the intensive therapy wards, pediatric and general wards. The authors indicate that because 
of the prevalence of airborne pathogenic $S$. aureus bacteria, the air quality has to be controlled.

Mandal et al. (2015) demonstrated that S. aureus bacteria, including antibiotic-resistant (also multiantibiotic-resistant) strains, were present in the wastewater discharged from hospitals. These wastes are supplied to the wastewater treatment plant, where they first constitute a source of exposure to those bacteria for workers and second become a potential threat to the environment. It was shown that in the treated water that is discharged into the environment (natural water reservoirs, soil), viable pathogens are still present, including $S$. aureus (Mandal et al. 2015).

\section{Concentrated animal feed operations}

In the concentrated animal feed operation (CAFO), antibiotics are used preventively, before the first symptoms of the disease occur, which promotes spreading of antibiotic resistance (McCarthy et al. 2012; Love et al. 2011). Animal husbandry workers through their occupational contact become carriers, and consequently, bacteria with resistance genes may be conveyed to their families (Alvarado et al. 2009; Nadimpalli et al. 2018).

Ferguson et al. (2016) conducted the research on the identification of methicillin-resistant $S$. aureus (MRSA) in the indoor air of husbandry buildings and around them and also in the fodder prepared for the animals before they are brought to the breeding building and inside the building. Analysis of the size of viable particles was conducted using a 6-stage air sampler-Andersen. MRSA strains were found in all samples: in fodder and indoor air, they were present both in smaller particles and those bigger than $5 \mu \mathrm{m}$, whereas in atmospheric air at a distance of $215 \mathrm{~m}$, they were found exclusively in particles smaller than $5 \mu \mathrm{m}$. The presence of MRSA in fodder before it was brought into the building points to a probability that fodder also can be a source of those bacteria. The mean concentration of MRSA on particles bigger than $5 \mu \mathrm{m}$ in the samples from the pig house indoor air reached the value of $825 \mathrm{CFU} / \mathrm{m}^{3}$ and MRSA on the particles smaller than $5 \mu \mathrm{m}$ reached $188 \mathrm{CFU} / \mathrm{m}^{3}$, whereas in outdoor air samples, it was $5 \mathrm{CFU} / \mathrm{m}^{3}$. For further research, 12 isolates of Staphylococcus aureus from the indoor air were analysed, 100\% of which exhibited resistance to methicillin, $67 \%$ to tetracycline and clyndamycine, and $33 \%$ to erythromycin. Air sampling was also done after washing and disinfection of the pig house, and MRSA was not found there, which demonstrates that disinfection of interiors may be an effective form of preventing the airborne MRSA transmission.

To identify the sources of the origin of $S$. aureus in bioaerosol, inside 4 poultry farms, the samples of air and poultry faeces were collected; besides, the atmospheric air samples were collected at different distances from the buildings. The concentration of $S$. aureus bacteria inside the henhouses reached the values of $23,27,47$, and $51 \mathrm{CFU} / \mathrm{m}^{3}$, considerably exceeding the concentrations identified in atmospheric air samples $\left(1,2,4,5,10,8\right.$, and $\left.9 \mathrm{CFU} / \mathrm{m}^{3}\right)$. Molecular methods applied in the research demonstrated a genetic similarity of isolated strains; $60 \%$ of $S$. aureus isolates present in the indoor air samples originated from manure samples. The results suggest that such pathogens as $S$. aureus while disseminating from manure to bioaerosol inside and outside the breeding facilities may constitute a potential source of infection (Zhong et al. 2009).

Liu et al. (2012) carried out some studies on the transmission of antibiotic-resistant genes of $S$. aureus strains in the environment. For this aim on 6 poultry farms, the samples of manure and indoor air in farming buildings and outdoor air were collected and analysed on the presence of $S$. aureus strains. Of 149 isolates with subtyped species, 15 types of antibiotics resistance were confirmed and 8 isolates exhibited resistance to methicillin. A high index of genetic probability at the level of 47.3-72.2\% was shown between the isolates coming from the air, some of them exhibiting a $100 \%$ similarity to isolates sampled from manure. It has been demonstrated that multiantibiotic-resistant strains of pathogenic bacteria spreading in the air pose a risk to the health of the exposed people, thereby constituting a significant problem in public health.

Madsen et al. (2018a) conducted the study aimed at the measurement of the airborne MRSA and S. aureus particle sizes in the pig farms environment. The obtained results allow to conclude about the potential deposition of the bacteria in different parts of the exposed workers' airways. The presence of the airborne $S$. aureus was identified in all 44 samples collected on the four farms using the six-stage Andersen sampler, and then, an analysis was made using MALDI-TOF MS method while MRSA was confirmed using the same methods in 31 of 33 samples collected on the three farms. The comparison of the geometric mean concentrations of $S$. aureus $\left(1.8 \times 10^{3} \mathrm{CFU} / \mathrm{m}^{3}\right)$ and MRSA ( $447 \mathrm{CFU} / \mathrm{m}^{3}$ ) indicates that MRSA constitutes approx. $25 \%$ of the $S$. aureus concentration. The highest and lowest concentrations of the total inhalable MRSA were found in the empty stable during a high-pressure cleaning and in a stable with sick pigs, respectively. The highest and lowest concentrations of $S$. aureus were shown in a weaner stable and in feed storages, respectively. Analysis of the particle sizes indicated that most airborne $S$. aureus and MRSA strains were associated with particles between 7 and $12 \mu \mathrm{m}$ and that the total inhalable MRSA and $S$. aureus concentration (100\%) could be potentially deposited in the human respiratory system: in the upper airways $70 \%$, in the primary and secondary bronchi $22 \%$, and in the terminal bronchi and alveoli 8\% (Madsen et al. 2018a).

\section{Wastewater treatment plant}

Wastewater treatment plants may be a link in spreading of pathogenic bacteria to the environment. According to Berendonk et al. (2015), very high concentrations of bacteria, including pathogenic ones, and subtherapeutic concentrations 
of antibiotics present in wastewater treatment plants, result in introducing - to the environment - the antibiotic-resistant bacteria and genes resistant to antibiotics. Rosenberg Goldstein et al. (2012) analysed samples of wastewater collected in four wastewater treatment plants in the USA in view of the presence of those bacteria in all the investigated wastewater treatment plants in view of the occurrence of MRSA and MSSA strains. Those bacteria were found in all the investigated wastewater treatment plants; MRSA was present in $50 \%$ of the samples (24 of 44 samples), whereas MSSA was found in $55 \%$ (22 of 44) of the samples. Most of the MRSA strains and almost one third of MSSA (29\%) exhibited resistance to two or more classes of antibiotics. According to the results of those studies, Kessler (2012) concludes that the confirmation of the presence of $S$. aureus bacteria in the wastewater of WWTPs explicitly indicates a high risk of exposure for WWTP workers and the people who live, work, or spend their time around more and more numerous agricultural and recreational areas irrigated with reclaimed wastewater. The presence of MRSA in the wastewater subjected to irrigation was indicated empirically (Börjesson et al. 2010). Moreover, Thompson et al. (2013) proved that MRSA strains present in wastewater originated from hospitals (HA-MRSA) can survive through all stages of treatment and are present in reclaimed wastewater. The same opinion as regards bacteria and genes of resistance present in wastewater was expressed by Baquero et al. (2008). Apart from hospitals, an important source of antibiotic-resistant $S$. aureus strains is concentrated animal feed operations (Harper et al. 2010). Wan and Chou (2014) analysed wastewater coming from slaughter houses of pigs in view of the prevalence of LA-MRSA and mecA genes (the gene coding resistance to methicillin) and showed the presence of both agents in high concentrations.

The wastewater treatment processes generate high amounts of bioaerosol. This is mainly due to the processes of mixing, overflowing, and aeration necessary to the biological treatment, which, however, cause splashing, bubbling, and spraying (Fracchia et al. 2006). The respiratory tract can be a significant route of infection for WWTP employees (Bos et al. 2016). Protecting of the respiratory tract from exposure to high concentrations of microorganisms still is a challenge in a field of occupational safety and hygiene. Although in developed countries, the masks with biological filters are commonly available and used in practice, yet it was shown empirically that such masks had some defects. Majchrzycka et al. (2016) tested the survivability of certain species of microorganisms on the filtration fabric from masks protecting the respiratory tract and showed that it was the $S$. aureus species that with available 40-200\% humidity exhibited the highest survivability.

Fracchia et al. (2006) conducted the research aimed at assessment of the level of air pollution with bacterial microflora (including pathogenic) in two wastewater treatment plants with different treatment technologies in Italy. It was demonstrated that the $S$. aureus species was present in the air both in summer and winter season, but no correlation was found between the season and bacteria airborne concentration. The results confirm an increased risk of infection in wastewater treatment plant workers and point to the need for rigorous use of preventive measures. Much more frequently, the research conducted in the wastewater treatment plant environments related to the identification of airborne bacteria only to the level of Staphylococcus genus (De Luca et al. 2001; Gotkowska-Płachta et al. 2013; Han et al. 2018; Uhrbrand et al. 2017).

Michałkiewicz et al. (2011) analysed the microflora present in atmospheric air in different sites of the wastewater treatment plant in different seasons in Poland and confirmed the presence of, among other, $S$. aureus species in bioaerosol. Vantarakis et al. (2016) tested also the qualitative composition of bacterial microflora in immediate vicinity of the municipal wastewater treatment plant $(500 \mathrm{~m})$. For species identification, randomly selected were 83 bacterial isolates among which $29 \%$ (24 isolates) were those of $S$. aureus genus.

\section{Public places and homes}

Li et al. (2015) conducted a study aimed at the confirmation of the presence of $S$. aureus bacteria, including MRSA strains, in indoor air of various public buildings in China in spring, analysing inhalable and respirable fractions. For both analysed fractions of bioaerosol, the highest concentration of $S$. aureus, presented as the median $\left(84 \mathrm{CFU} / \mathrm{m}^{3}\right.$ for inhalable fraction and $57 \mathrm{CFU} / \mathrm{m}^{3}$ for respirable fraction), and also MRSA strains $\left(33 \mathrm{CFU} / \mathrm{m}^{3}\right.$ for inhalable fraction and $18 \mathrm{CFU} / \mathrm{m}^{3}$ for respirable fraction), was identified at the cinema hall. Moon et al. (2014) conducted the studies aimed mainly at the identification of microorganisms isolated from the air inside the flats in South Korea. The predominant bacteria were Staphylococcus (which constituted 49-61.3\% of all microfloras). The presence of $S$. aureus species was confirmed in all investigated apartments in $4-140 \mathrm{CFU} / \mathrm{m}^{3}$ concentrations. MRSA was isolated from air samples from $66 \%$ of apartments covered by the measurements.

Messi et al. (2015) conducted the research in different environments, including public places in Italy, related to the identification of bacteria exhibiting antibiotics resistance. Air samples were collected from restaurants, fitness clubs, offices, houses, and classrooms, as well as operating rooms, dentists' surgeries, and waste management plants. Among 280 analysed isolates, $17 \%$ were classified to Staphylococcus genus, within which the presence of five $S$. aureus isolates belonging to two different strains was found. Two $S$. aureus isolates exhibited resistance to erythromycin and tetracycline. Pastuszka et al. (2000) analysed the concentration of microorganisms in indoor air of flats. Samples of bioaerosol in the flats were collected in summer and winter seasons; the atmospheric air constituted the outdoor background of the study. In the identified microflora was a 
present $S$. aureus strain (7.8\% of the total bacterial microflora). A similar study was conducted by Gandara et al. (2006) who in Texas isolated from the flats' indoor air the $S$. aureus bacteria in average concentration of $15 \mathrm{CFU} / \mathrm{m}^{3}$, whereas in 23 samples collected outdoors, the mean concentration of $S$. aureus reached $12 \mathrm{CFU} / \mathrm{m}^{3}$. The analysis of antibiotic resistance showed the presence of $S$. aureus strains resistant to penicillin and ampicillin (in 22 flats) and to cefaclor (in 14 flats).

The studies demonstrate that Staphylococcus spp. bacteria resistant to various groups of antibiotics are present in public transport means, and passengers' migration at transfer stations provides conducive conditions to the dissemination of antibioticresistant strains (Lin et al. 2016; Peng et al. 2015; Zhou and Wang 2013), including also MRSA (Conceição et al. 2013).

Wlazło et al. (2008) conducted in Poland the study aimed at the evaluation of library staff's exposure to biological hazards. In the samples collected from the bioaerosol and dust settled on book surfaces, 53 species of bacteria belonging to 20 genera were identified. The qualitative analysis of the bacteria of Staphylococcus genus showed the presence of 14 species, including $S$. aureus. The studies on microbiological quality of air in 8 libraries of Ethiopia were conducted by Hayleeyesus and Manaye (2014). In total, 96 air samples were collected and microorganisms were identified, among which $S$. aureus was isolated.

Also in Poland, Lenar-Boroń et al. (2014) carried out a similar study, but they collected the air samples at a students' hostel. In the collected bioaerosol, Staphylococcus bacteria were isolated and identified to the species, and subsequently, their antibiotics resistance was analysed. Of the total of 5 species of staphylococci, $S$. aureus resistant to erythromycin and clindamycine was isolated.

\section{Methodological catalogue}

According to the literature (Agersø et al. 2013; Madsen et al. 2019), the correct option from the variety of methods of air sampling for microbiological analysis requires the huge knowledge and long experience in the field study. Many different factors can influence the result, such as the concentration of airborne microorganisms (closely related with the type of environment), relative humidity ( $\mathrm{RH})$, temperature, species composition, and their ability to survive under unfavourable conditions. Therefore, it is important to select not only the sampling method and the type of the air sampler, but also the appropriate sampling conditions (the most important are time, air volume, and air flow rate). The next critical step is the selection of the type of medium (e.g. enriched or selective and differential media), cultivation conditions, and identification or molecular typing. The laboratory recommendations related to the microbiological analysis of $S$. aureus including MRSA strains are described in detail in literature and are updating according to the current state of the knowledge (Deplano et al. 2018; Missiakas and Schneewind 2013; Vitko and Richardson 2013).

According to the literature, a modern and expensive equipment is not always better than the traditional methods of sampling. Smith et al. (2018) in a study conducted to assess the cleanliness of a hospital intensive care unit analysed samples from surfaces and from the air (sampled by passive and active methods) on the presence of $S$. aureus and MRSA. The results obtained from surfaces and air were compared, and their analysis indicates that the sedimentation method is in line with the results of the surface study. The authors concluded that the settle plates could be applied for routine environmental screening to determine the infection risk in intensive care units.

However, if there is a necessity to confirm species or strains, the MALDI-TOF MS method (matrix-assisted laserdesorption/ionization time-of-flight mass spectrometry) or genetic methods have eliminated the risk of erroneous identification. Currently, the trend in the use of these two methods of microorganism identification has changed; MALDI-TOF has become a standard in both clinical and scientific research, in which genetic methods have been more prominent until recently. Due to the inconsistencies of the genetic techniques, i.e. high price, necessity of participation of specialized personnel, and relatively high time-consuming procedure, more and more laboratories use microbial identification by MALDITOF. The advantages of MALDI-TOF MS involve simplicity of sample preparation, relatively low costs, and fast analysis with high reliability of results comparable with the subtyping. Owing to these assets, the MALDI-TOF MS has become a standard in microbiology (Kostrzewa and Nagy 2016).

Madsen et al. (2019) conducted the study which can be a basis for the description of relevant differences in results (understood as the concentration of airborne MRSA) between six methods of sampling of airborne MRSA (five active and one passive) on five pig farms. Identification of bacteria was carried out on selective agar media using the MALDI-TOF MS method. The study showed a variation in bacteria concentrations between different methods of sampling. Geometric mean concentrations were in the range of $1450-2000 \mathrm{CFU} / \mathrm{m}^{3}$ and $110-419 \mathrm{CFU} / \mathrm{m}^{3}$, for $\mathrm{S}$. aureus and MRSA, respectively. The authors tested also the active sampling methods for the half-life of bacteria, and the survival of $S$. aureus and MRSA was studied for day 0-day 6 after sampling. The study showed no significant effect of the active sampling method during $1 \mathrm{~h}$ on the half-life of studied pathogens, but the passive sampling should not exceed 3 days due to overloading and the die-off of MRSA. The authors found a significant correlation between the dust and $S$. aureus concentration within farm section and different farms but not in all the investigated facilities. The results showed a high spatial and temporal variation of bacteria concentrations; therefore, the authors concluded that to obtain a reliable picture of a potential exposure, samples should be taken repeatedly and in different areas within a stable section. 


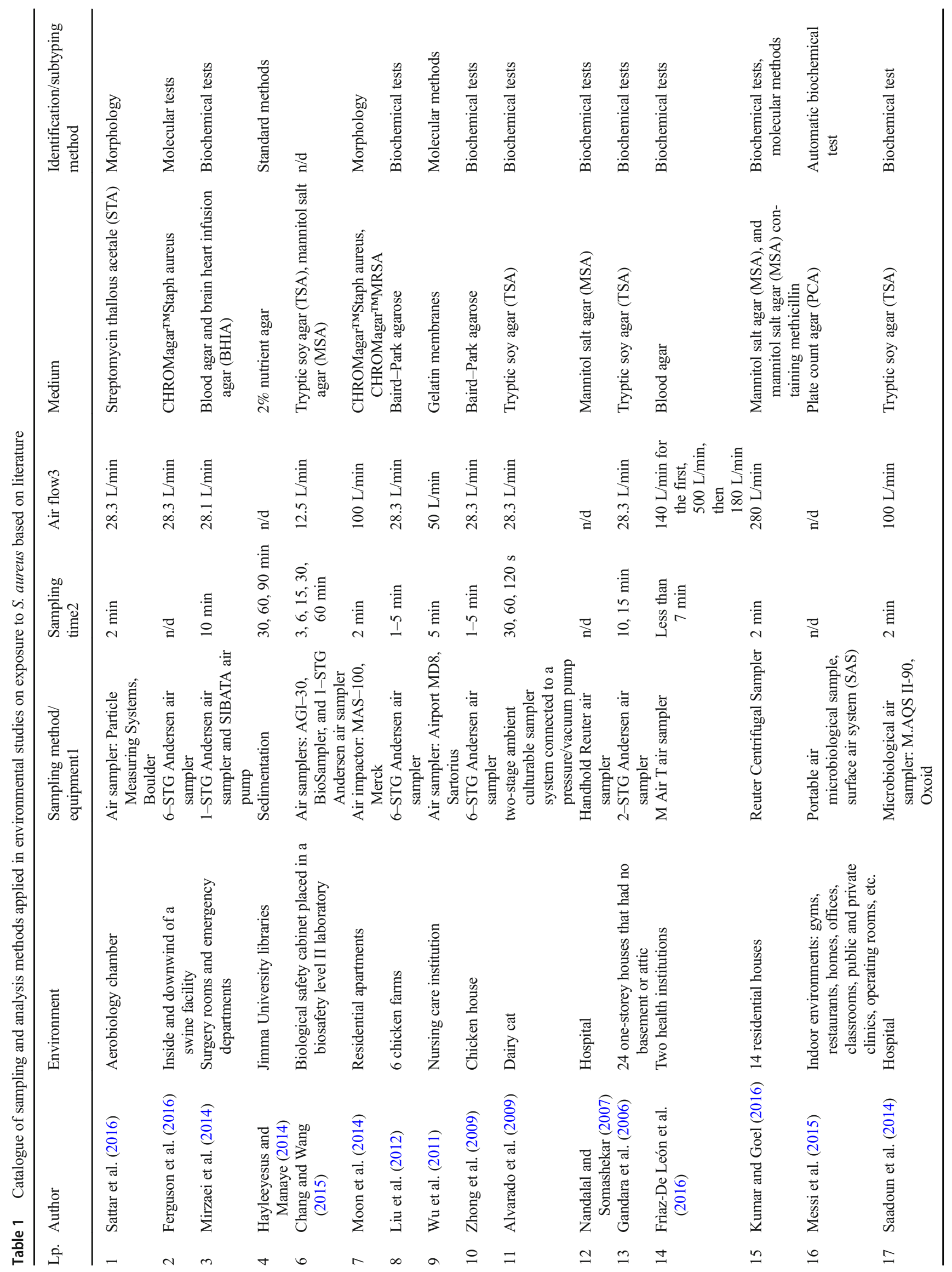




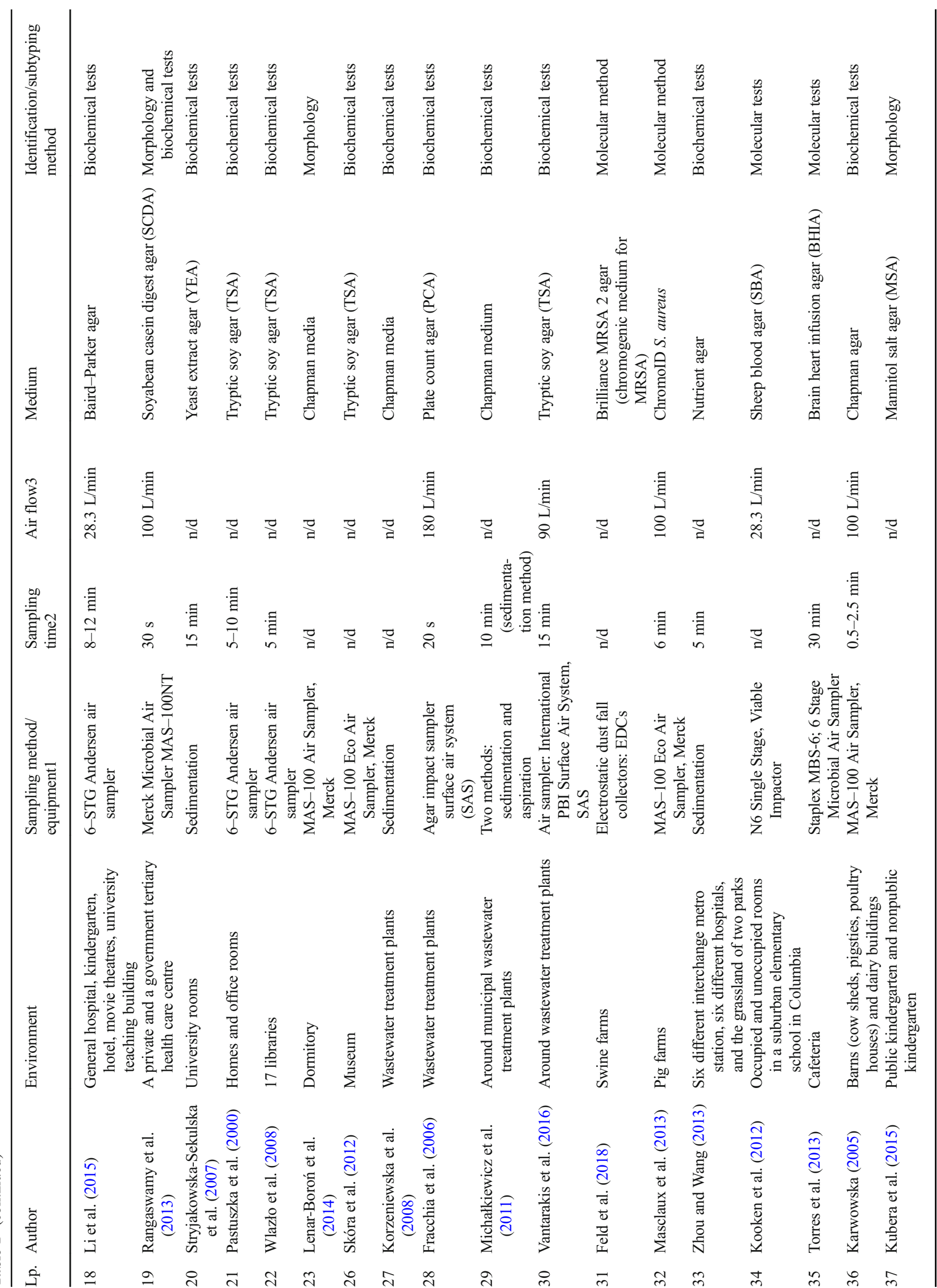




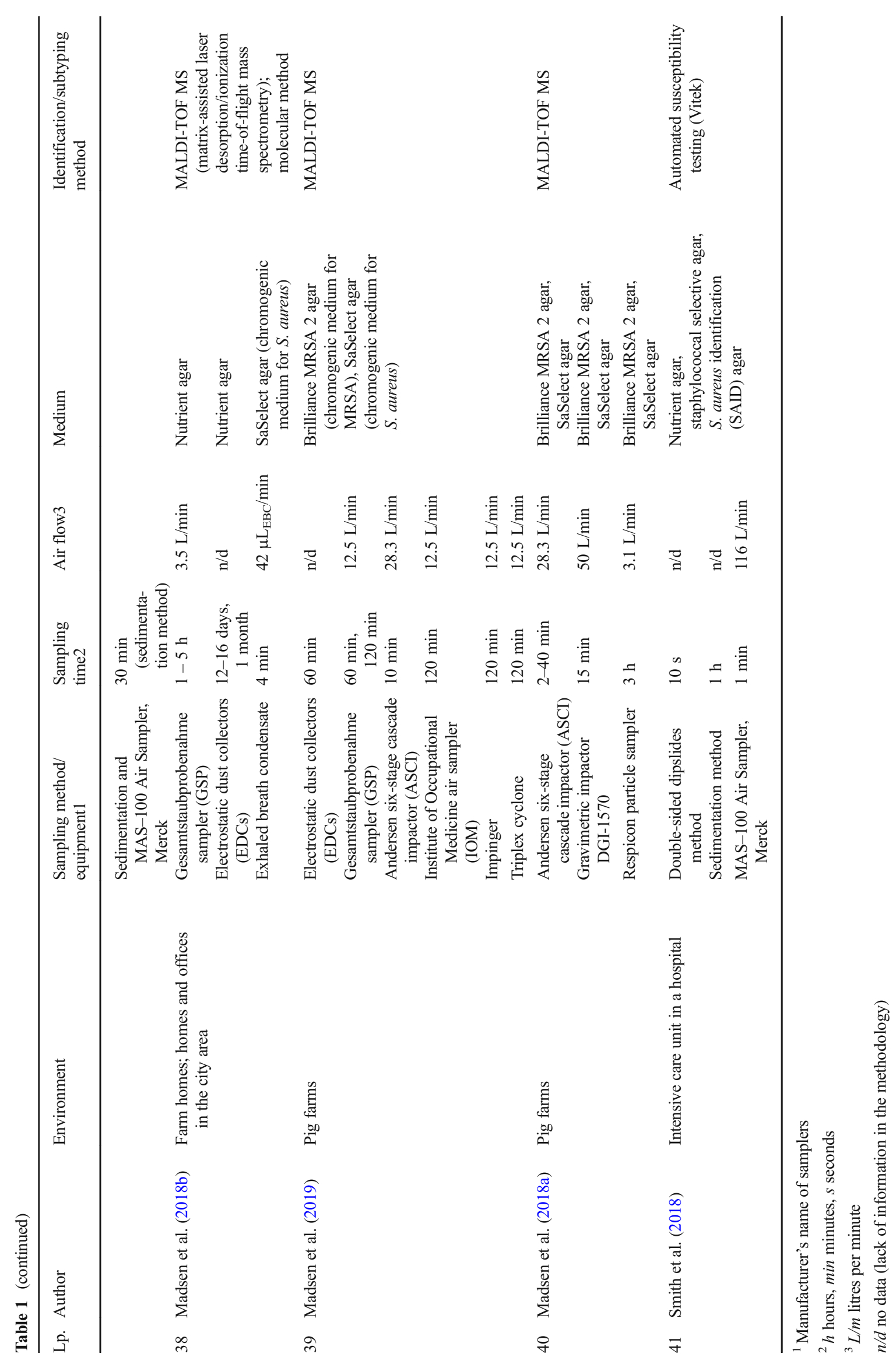


On the basis of the literature selected for the review, the methods of sampling and identification or subtyping of S. aureus including MRSA strains were catalogued and presented in Table 1.

\section{Conclusions}

The literature review points to a common presence of airborne $S$. aureus bacteria in different environments. In the air was confirmed also presence of multiantibiotics-resistant strains, including MRSA. The presented results of the research demonstrate that a particular risk for public health, apart from hospitals, refers to the environment of wastewater treatment plants and livestock husbandry, where the high concentrations of $S$. aureus, including antibiotic-resistant strains, were shown.

The role of the airborne transmission in dissemination of infections caused by these pathogens in groups exposed in occupational environments has been empirically confirmed. However, there is still a need to extend the knowledge on the significance of this route in $S$. aureus infection spreading in humans, particularly in the general population.

Modern methods of identification, especially the MALDITOF MS, create the possibility to fastly analyse the origin of strains isolated from the air and to confirm their source. The investigations of the tracts of the MRSA transmission in the air (LA-MRSA, HA-MRSA, and LA-MRSA) need to be carried on a much wider scale than currently to prevent the transfer of resistance genes and infections caused by these strains in human.

Funding information The project was financed with a grant No 6/4/3.1 h/NPZ/2016/312/1659/B under Poland's National Health Program for 2016-20. Operational objective 4. Reducing the health risk resulting from physical, chemical, and biological hazards in the external, occupational, residential, recreational, and educational environment; other supporting tasks include monitoring, including monitoring of physical, chemical, and biological hazards in the workplace, i.e. exposure to pathogenic Staphylococcus aureus bacteria present in bioaerosol in wastewater treatment plant workers. head Anna Kozajda, PhD.

Open Access This article is distributed under the terms of the Creative Commons Attribution 4.0 International License (http:// creativecommons.org/licenses/by/4.0/), which permits unrestricted use, distribution, and reproduction in any medium, provided you give appropriate credit to the original author(s) and the source, provide a link to the Creative Commons license, and indicate if changes were made.

\section{References}

Agersø Y, Vigre H, Cavaco LM, Josefsen MH (2013) Comparison of air samples, nasal swabs, ear-skin swabs and environmental dust samples for detection of methicillin-resistant Staphylococcus aureus (MRSA) in pig herds. Epidemiol Infect 142:1727-1736
Agostino JW, Ferguson JK, Eastwood K, Kirk MD (2017) The increasing importance of community-acquired methicillin-resistant Staphylococcus aureus infections. Med J Aust 207(9):388-393. https://doi.org/10.5694/mja17.00089

Alvarado C, Gandara A, Flores C, Perez H et al (2009) Seasonal changes in airborne fungi and bacteria at a dairy cattle concentrated animal feeding operation in the Southwest United States. J Environ Health 9(71):40-44

Angen Ø, Feld L, Larsen J, Rostgaard K et al (2017) Transmission of methicillin-resistant Staphylococcus aureus to human volunteers visiting a swine farm. Appl Environ Microbiol 83(23):e01489 e01417. https://doi.org/10.1128/AEM.01489-17

Antonanzas F, Lozano C, Torres C (2015) Economic features of antibiotic resistance: the case of methicillin-resistant Staphylococcus aureus. Pharmacoeconomics 33(4):285-325. https://doi.org/10.1007/ s40273-014-0242-y

Arias CA, Murray BE (2015) A new antibiotic and the evolution of resistance. N Engl J Med 372(12):1168-1170. https://doi.org/10. 1056/NEJMcibr1500292

Baba T, Takeuchi F, Kuroda M, Yuzawa H et al (2002) Genome and virulence determinants of high virulence community-acquired MRSA. Lancet 359(9320):1819-1827. https://doi.org/10.1016/ S0140-6736(02)08713-5

Baquero F, Martinez JL, Cantón R (2008) Antibiotics and antibiotic resistance in water environments. Curr Opin Biotechnol 19(3):260 265. https://doi.org/10.1016/j.copbio.2008.05.006

Beard-Pegler MA, Stubbs E, Vickery AM (1988) Observations on the resistance to drying of staphylococcal strains. J Med Microbiol 26(4):251-255

Becker K, Ballhausen B, Köck R, Kriegeskorte A (2014) Methicillin resistance in Staphylococcus isolates: the "mec alphabet" with specific consideration of mecC, a mec homolog associated with zoonotic S. aureus lineages. Int J Med Microbiol 304(7):794-804. https://doi.org/10.1016/j.ijmm.2014.06.007

Beggs C (2003) The airborne transmission of infection in hospital buildings: Fact or fiction? Indoor Built Environ 12(1-2):9-18. https://doi. org/10.1177/1420326X03012001002

Berendonk TU, Manaia CM, Merlin C, Fatta-Kassinos D et al (2015) Tackling antibiotic resistance: the environmental framework. Nat Rev Microbiol 13(5):310-317. https://doi.org/10.1038/nrmicro3439

Boopathy R (2017) Presence of methicillin resistant Staphylococcus aureus (MRSA) in sewage treatment plant. Bioresour Technol 240: 144-148. https://doi.org/10.1016/j.biortech.2017.02.093

Börjesson S, Matussek A, Melin S, Löfgren S, Lindgren PE (2010) Methicillin-resistant Staphylococcus aureus (MRSA) in municipal wastewater: an uncharted threat? J Appl Microbiol 108(4):1244 1251. https://doi.org/10.1111/j.1365-2672.2009.04515.x

Bos ME, Verstappen KM, van Cleef BA, Dohmen W et al (2016) Transmission through air as a possible route of exposure for MRSA. J Expo Sci Environ Epidemiol 26(3):263-269. https://doi. org/10.1038/jes.2014.85

Boyce JM (2007) Environmental contamination makes an important contribution to hospital infection. J Hosp Infect 65(2):50-54. https://doi. org/10.1016/S0195-6701(07)60015-2

Boyce JM, Cookson B, Christiansen K, Hori S et al (2005) Meticillinresistant Staphylococcus aureus. Lancet Infect Dis 5(10):653-663. https://doi.org/10.1016/S1473-3099(05)70243-7

Centers for Disease Control and Prevention (CDC). Antibiotic resistance threats in the United States, 2013. Atlanta: CDC; 2013. Available from: https://www.cdc.gov/drugresistance/pdf/ar-threats-2013-508. pdf

Chang CW, Lin MH (2018) Optimization of PMA-qPCR for Staphylococcus aureus and determination of viable bacteria in indoor air. Indoor Air 28(1):64-72. https://doi.org/10.1111/ina.12404 
Chang C, Wang L (2015) Impact of culture media and sampling methods on Staphylococcus aureus aerosols. Indoor Air 25(5):488-498. https://doi.org/10.1111/ina.12162

Chen LF (2013) The changing epidemiology of methicillin-resistant Staphylococcus aureus: 50 years of a superbug. Am J Infect Control 41(5):448-451. https://doi.org/10.1016/j.ajic.2012.06.013

Claus F, Sachse A, Ried W (2014) On the economic burden of MRSA in Germany. Gesundheitswesen 76(12):800-806. (in German). https:// doi.org/10.1055/s-0034-1381987

Conceição T, Diamantino F, Coelho C, de Lencastre H, Aires-de-Sousa M (2013) Contamination of public buses with MRSA in Lisbon, Portugal: a possible transmission route of major MRSA clones within the community. PLoS One 8(11):77812. https://doi.org/10.1371/ journal.pone.0077812

Conlon B (2014) Staphylococcus aureus chronic and relapsing infections: evidence of a role for persister cells: an investigation of persister cells, their formation and their role in S. aureus disease. Bioessays 36(10):991-996. https://doi.org/10.1002/bies.201400080

Daum R (2007) Skin and soft - tissue infections caused by methicillinresistant Staphylococcus aureus. New Engl J Med 357(4):380-390. https://doi.org/10.1056/NEJMcp070747

David MZ, Cadilla A, Boyle-Vavra S, Daum RS (2014) Replacement of HA-MRSA by CA-MRSA infections at an academic medical center in the midwestern United States, 2004-5 to 2008. PLoS One 9(4): e92760. https://doi.org/10.1371/journal.pone.0092760

Davis M, Iverson S, Baron P, Vasse A et al (2012) Household transmission of meticillin - resistant Staphylococcus aureus and other staphylococci. Lancet Infect Dis 12(9):703-716. https://doi.org/10.1016/ S1473-3099(12)70156-1

De Luca G, Zanetti F, Chiara Perari A, Stampi S (2001) Airborne coagulase negative staphylococci by a sewage treatment plant. Int J Hyg Environ Health 204(4):231-238. https://doi.org/10.1078/14384639-00098

DeLeo FR, Otto M, Kreiswirth BN, Chambers HF (2010) Communityassociated meticillin resistant Staphylococcus aureus. Lancet 375(9725):1557-1568. https://doi.org/10.1016/S0140-6736(09) $61999-1$

Denayer S, Delbrassinne L, Nia Y, Botteldoorn N (2017) Food-borne outbreak investigation and molecular typing: high diversity of Staphylococcus aureus strains and importance of toxin detection. Toxins (Basel) 9(12):407. https://doi.org/10.3390/toxins9120407

Denis O (2017) Route of transmission of Staphylococcus aureus. Lancet Infect Dis 17(2):124-125. https://doi.org/10.1016/S1473-3099(16) 30512-6

Deplano A, Dodémont M, Denis O, Westh H et al (2018) European external quality assessments for identification, molecular typing and characterization of Staphylococcus aureus. Antimicrob Chemother 73(10):2662-2666. https://doi.org/10.1093/jac/dky260

Duckworth GJ, Jordens JZ (1990) Adherence and survival properties of an epidemic methicillin-resistant strain of Staphylococcus aureus compared with those of methicillin-sensitive strains. J Med Microbiol 32(3):195-200

Epstein L, Mu Y, Belflower R, Scott J et al (2016) Risk factors for invasive methicillin-resistant Staphylococcus aureus infection after recent discharge from an acute-care hospitalization, 2011-2013. Clin Infect Dis 62(1):45-52. https://doi.org/10.1093/cid/civ777

Farrington M, Brenwald N, Haines D, Walpole E (1992) Resistance to desiccation and skin fatty acids in outbreak strains of methicillinresistant Staphylococcus aureus. J Med Microbiol 36(1):56-60

Feld L, Bay H, Angen Ø, Larsen AR, Madsen AM (2018) Survival of LA-MRSA in dust from swine farms. Ann Work Expo Health 62(2): 147-156. https://doi.org/10.1093/annweh/wxx108

Ferguson D, Smith T, Hanson B, Wardyn S, Donham K (2016) Detection of airborne methicillin - resistant Staphylococcus aureus inside and downwind of a swine building, and in animal feed: potential occupational, animal health, and environmental implications. J
Agromedicine 21(2):149-153. https://doi.org/10.1080/1059924X. 2016.1142917

Foster TJ (2005) Immune evasion by staphylococci. Nat Rev Microbiol 3(12):948-958. https://doi.org/10.1038/nrmicro1289

Foster TJ (2009) Colonization and infection of the human host by staphylococci: adhesion, survival and immune evasion. Vet Dermatol 20(5-6):456-470. https://doi.org/10.1111/j.1365-3164.2009.00825.

Foster TJ, Hook M (1998) Surface protein adhesins of Staphylococcus aureus. Trends Microbiol 6(12):484-488. https://doi.org/10.1016/ S0966-842X(98)01400-0

Fracchia L, Pietronave S, Rinaldi M, Giovanna Martinotti M (2006) Site - related airborne biological hazard and seasonal variations in two wastewater treatment plants. Water Res 40(10):1985-1994. https:// doi.org/10.1016/j.watres.2006.03.016

Frank DN, Feazel LM, Bessesen M, Price CS, Janoff EN, Pace NR (2010) The human nasal microbiota and Staphylococcus aureus carriage. PLoS One 5(5):e10598. https://doi.org/10.1371/journal.pone. 0010598

Frìaz-De León MG, Duarte-Escalante E, del Calderón-Ezquerro M, del Jiménez-Martìnez M et al (2016) Diversity and characterization of airborne bacteria at two health institutions. Aerobiologia 32:187198. https://doi.org/10.1007/s10453-015-9389-z

Friese A, Schulz J, Zimmermann K, Tenhagen B et al (2013) Occurrence of livestock - associated methicillin - resistant Staphylococcus aureus in turkey and broiler barns and contamination of air soil surfaces in their vicinity. Appl Environ Microbiol 79(8):27592766. https://doi.org/10.1128/AEM.03939-1

Gandara A, Mota L, Flores C, Perez H (2006) Isolation of Staphylococcus aureus and antibiotic - resistant Staphylococcus aureus residential bioaerosols. Environ Health Perspect 12(114):1859-1864. https:// doi.org/10.1289/ehp. 9585

Gordon RJ, Lowy FD (2008) Pathogenesis of methicillin-resistant Staphylococcus aureus infection. Clin Infect Dis 46(5):350-359. https://doi.org/10.1086/533591

Gotkowska-Płachta A, Filipkowska Z, Korzeniewska E, Janczukowicz $\mathrm{W}$ et al (2013) Airborne microorganisms emitted from wastewater treatment plant treating domestic wastewater and meat processing industry wastes. Clean - Soil, Air, Water 41(5):429-436. https://doi. org/10.1002/clen.201100466

Gould IM, David MZ, Esposito S, Garau J et al (2012) New insights into meticillin-resistant Staphylococcus aureus (MRSA) pathogenesis, treatment and resistance. Int J Antimicrob Agents 39(2):96-104. https://doi.org/10.1016/j.ijantimicag.2011.09.028

Gupta M, Bisesi M, Lee J (2017) Comparison of survivability of Staphylococcus aureus and spores of Aspergillus niger on commonly used floor materials. Am J Infect Control 45(7):717-722. https:// doi.org/10.1016/j.ajic.2017.02.014

Han Y, Wang Y, Li L, Xu G, Liu J, Yang K (2018) Bacterial population and chemicals in bioaerosols from indoor environment: sludge dewatering houses in nine municipal wastewater treatment plants. Sci Total Environ 618:469-478. https://doi.org/10.1016/j.scitotenv. 2017.11.071

Harper AL, Ferguson DD, Leedom Larson KR, Hanson BM et al (2010) An overview of livestock - associated MRSA in agriculture. J Agromedicine 15(2):101-104. https://doi.org/10.1080/ 10599241003627110

Hayleeyesus S, Manaye A (2014) Microbiological quality of indoor air in University Libraries. Asian Pac J Trop Biomed 4(1):312-317. https://doi.org/10.12980/APJTB.4.2014C807

Hennekinne JA, De Buyser ML, Dragacci S (2012) Staphylococcus aureus and its food poisoning toxins: characterization and outbreak investigation. FEMS Microbiol Rev 36(4):815-836. https://doi. org/10.1111/j.1574-6976.2011.00311.x

Hübner NO, Hübner C, Kramer A, Assadian O (2011) Survival of bacterial pathogens on paper and bacterial retrieval from paper to hands: 
preliminary results. Am J Nurs 111(12):30-34. https://doi.org/10. 1097/01.NAJ.0000408181.37017.82

Karwowska E (2005) Microbiological air contamination in farming environment. Pol J Environ Stud 4(14):445-449

Kessler R (2012) Superbug hideout: finding MRSA in U.S. wastewater treatment plants. Environ Health Perspect 120(11):A437. https://doi. org/10.1289/ehp.120-a437a

Keynan Y, Rubinstein E (2013) Staphylococcus aureus bacteremia, risk factors, complications, and management. Crit Care Clin 29(3):547562. https://doi.org/10.1016/j.ccc.2013.03.008

Köck R, Becker K, Cookson B, van Gemert-Pijnen JE et al (2010) Methicillin-resistant Staphylococcus aureus (MRSA): burden of disease and control challenges in Europe. Euro Surveill 15(41):19688. https://doi.org/10.2807/ese.15.41.19688-en

Kooken JM, Fox KF, Fox A (2012) Characterization of Micrococcus strains isolated from indoor air. Mol Cell Probes 26(1):1-5. https:// doi.org/10.1016/j.mcp.2011.09.003

Korzeniewska E, Filipkowska Z, Gotkowska-Płachta A, Janczukowicz W (2008) Bacterial air pollution in the area and in the vicinity of the sewage treatment plant with a system of soil and plant filters. Water Environ Rural Areas 8(22):161-173 (in Polish)

Kostrzewa M, Nagy E (2016) How MALDI-TOF mass spectrometry can aid diagnosis of hard-to-identify pathogenic bacteria. Expert Rev Mol Diagn 16(5):509-511. https://doi.org/10.1586/14737159. 2016.1157019

Kraker ME, Wolkewitz M, Davey PG, Koller W et al (2011) Clinical impact of antimicrobial resistance in European hospitals: excess mortality and length of hospital stay related to methicillin - resistant Staphylococcus aureus bloodstream infections. Antimicrob Agents Chemother 4(55):1598-1605. https://doi.org/10.1128/AAC.01157-10

Kramer A, Schwebke I, Kampf G (2006) How long do nosocomial pathogens persist on inanimate surfaces? A systematic review. BMC Infect Dis 16(6):130. https://doi.org/10.1186/1471-2334-6-130

Kubera Ł, Studzińska J, Dokładna W, Małecka-Adamowicz M, Konderski W (2015) Microbiological air quality in some kindergardens and antibiotic resistance of bacteria of the Staphylococcus spp. genus. Med Pr 66(1):49-56 (in Polish) https://doi.org/10.13075/mp.5893.00162

Kumar P, Goel A (2016) Prevalence of methicillin resistant staphylococcal bioaerosols an and around residential houses in an urban area in central India. J Pathog. https://doi.org/10.1155/2016/7163615

Lee BY, Singh A, David MZ, Bartsch SM et al (2013) The economic burden of community-associated methicillin-resistant Staphylococcus aureus (CA-MRSA). Clin Microbiol Infect 19(6): 528-536. https://doi.org/10.1111/j.1469-0691.2012.03914.x

Lenar-Boroń A, Wolny-Koładka K, Kwaśniewska A (2014) Isolation, identification and assessment of drug resistance Staphylococci in University of Agriculture in Cracow. Polish J Agronomy 16:19-23 (in Polish)

Li X, Qiu Y, Yu A, Shi W et al (2015) Characteristics of airborne Staphylococcus aureus (including MRSA) in Chinese public buildings. Aerobiologia 31(1):11-19. https://doi.org/10.1007/s10453014-9342-6

Lin JL, Peng Y, Ou QT, Lin DX et al (2016) A molecular epidemiological study of methicillin - resistant Staphylococci environmental contamination in railway stations and coach stations in Guangzhou of China. Lett Appl Microbiol 64(2):131-137. https://doi.org/10.1111/ lam. 12700

Liu D, Chai T, Hia X, Gao Y et al (2012) Formation and transmission of Staphylococcus aureus (including MRSA) aerosols carrying antibiotic - resistant genes in a poultry farming environment. Sci Total Environ 426:139-145. https://doi.org/10.1016/j.scitotenv.2012.03.060

Long KS, Poehlsgaard J, Kehrenberg C, Schwarz S, Vester B (2006) The Cfr rRNA methyltransferase confers resistance to phenicols, lincosamides, oxazo-lidinones, pleuromutilins, and streptogramin A antibiotics. Antimicrob Agents Chemother 50(7):2500-2505. https://doi.org/10.1128/AAC.00131-06
Love D, Davis M, Bassett A, Gunther A, Nachman K (2011) Dose imprecision and resistance: free-choice medicated feeds in industrial food animal production in the United States. Environ Health Perspect 119(3):279-283. https://doi.org/10.1289/ehp.1002625

Lowy FD (1998) Staphylococcus aureus infections. N Engl J Med 339(8):520-532

Madsen AM, Kurdi I, Feld L, Tendal K (2018a) Airborne MRSA and total Staphylococcus aureus as associated with particles of different sizes on Pig Farms. Ann Work Expo Heal 62(8):966-977. https:// doi.org/10.1093/annweh/wxy065

Madsen AM, Moslehi-Jenabian S, Islam MZ, Frankel M et al (2018b) Concentrations of Staphylococcus species in indoor air as associated with other bacteria, season, relative humidity, air change rate, and S. aureus-positive occupants. Environ Res 160:282-291. https:// doi.org/10.1016/j.envres.2017.10.001

Madsen AM, Markouch A, Frederiksen MW, Tendal K (2019) Measurement of dust-borne MRSA in pig farms using different approaches. J Appl Microbiol 126(5):1580-1593. https://doi.org/10. 1111/jam. 14198

Majchrzycka K, Okrasa M, Skóra J, Gutarowska B (2016) Evaluation of the survivability of microorganisms deposited on filtering respiratory protective devices under varying conditions of humidity. Int $\mathrm{J}$ Environ Res Public Health 13(1):98. https://doi.org/10.3390/ ijerph13010098

Mandal SM, Ghosh AK, Pati BR (2015) Dissemination of antibiotic resistance in methicillin - resistant Staphylococcus aureus and vancomycin - resistant $S$. aureus strains isolated from hospital effluents. Am J Infect Control 43(12):87-88. https://doi.org/10.1016/j.ajic. 2015.08.015

Masclaux FG, Sakwinska O, Charrière N, Semaani E, Oppliger A (2013) Concentration of airborne Staphylococcus aureus (MRSA and MSSA), total bacteria, and endotoxins in pig farms. Ann Occup Hyg 57(5):550-557. https://doi.org/10.1093/annhyg/mes098

McCarthy AJ, Lindsay JA, Loeffler A (2012) Are all methicillin - resistant Staphylococcus aureus (MRSA) equal in all hosts? Epidemiological and genetic comparison between animal and human MRSA. Vet Dermatol 23(4):267-254. https://doi.org/10.1111/j. 1365-3164.2012.01072.x

Messi P, Sabia C, Anacarso I, Condo C et al (2015) Prevalence of multiresistant (MDR) bacteria in air samples from indoor and outdoor environments. Aerobiologia 31(3):381-387. https://doi.org/10. 1007/s10453-015-9371-9

Michałkiewicz M, Pruss A, Dymaczewski Z, Jeż-Walkowiak J, Kwaśna S (2011) Microbiological air monitoring around municipal wastewater treatment plants. Pol J Environ Stud 20(5):1243-1250

Mirzaei R, Shahriary E, Qureshi M, Rakhshkhorshid A et al (2014) Quantitative and qualitative evaluation of bio - aerosols in surgery rooms and emergency department of an educational hospital. Jundishapur J Microbiol 7(10):e11688. https://doi.org/10.5812/jjm. 11688

Missiakas DM, Schneewind O (2013) Growth and laboratory maintenance of Staphylococcus aureus. Curr Protoc Microbiol Chapter 9: Unit 9C.1. https://doi.org/10.1002/9780471729259.mc09c01s28

Moon KW, Huh EH, Jeong HC (2014) Seasonal evaluation of bioaerosols from indoor air of residential apartments within the metropolitan area in South Korea. Environ Monit Assess 186(4):2111-2120. https://doi.org/10.1007/s10661-013-3521-8

Moritz ED, Hanson BM, Kates AE, Smith TC (2015) Molecular characteristics of Staphylococcus aureus isolated from employees, children, and environmental surfaces in Iowa child daycare facilities. Am J Infect Control 43(5):482-488

Nadimpalli ML, Stewart JR, Pierce E, Pisanic N, Love DC, Hall D, Larsen J, Carroll KC, Tekle T, Perl TM, Heaney CD (2018) Face mask use and persistence of livestock-associated Staphylococcus aureus nasal carriage among industrial hog operation workers and 
household contacts, USA. Environ Health Perspect 126(12): 127005. https://doi.org/10.1289/EHP3453

Nandalal P, Somashekar R (2007) Prevalence of Staphylococcus aureus and Pseudomonas aeruginosa in indoor air flora of a district hospital, Mandya, Karnataka. J Environ Biol 28(2):197-200

Otter J, French G (2009) Bacterial contamination on touch surfaces in the public transport system and in public areas of a hospital in London. Lett Appl Microbiol 49(6):803-805. https://doi.org/10.1111/j.1472765X.2009.02728.x

Otto M (2010) Basis of virulence in community - associated methicillin resistant Staphylococcus aureus. Annu Rev Microbiol 64:143-162. https://doi.org/10.1146/annurev.micro.112408.134309

Parrish KL, Hogan PG, Clemons AA, Fritz SA (2018) Spatial relationships among public places frequented by families plagued by methicillin-resistant Staphylococcus aureus. BMC Res Notes. 2018 Oct 1;11(1):692. https://doi.org/10.1186/s13104-018-3797-4

Pastuszka J, Kyaw Tha Paw U, Lis D, Wlazło A, Ulfig K (2000) Bacterial and fungal aerosol in indoor environment in Upper Silesia, Poland. Atmos Environ 34(22):3833-3842. https://doi.org/10.1016/S13522310(99)00527-0

Paterson GK, Harrison EM, Holmes MA (2014) The emergence of mecC methicillin-resistant Staphylococcus aureus. Trends Microbiol 22(1):42-47. https://doi.org/10.1016/j.tim.2013.11.003

Patti JM, Allen BL, McGavin MJ, Höök M (1994) MSCRAMMmediated adherence of microorganisms to host tissues. Annu Rev Microbiol 48:585-617. https://doi.org/10.1146/annurev.mi.48. 100194.003101

Peng Y, Ou Q, Lin D, Xu P et al (2015) Metro system in Guangzhou as a hazardous reservoir of methicillin - resistant Staphylococci: findings from a point - prevalence molecular epidemiologic study. Sci Rep. https://doi.org/10.1038/srep16087

Rangaswamy B, Francis F, Prakash K, Manjunath N (2013) Variability in airborne bacterial and fungal population in the tertiary health care centre. Aerobiologia 29(4):473-479. https://doi.org/10.1007/ s10453-013-9297-z

Rosenberg Goldstein RE, Micallef SA, Gibbs SG, Davis JA et al (2012) Methicillin - resistant Staphylococcus aureus (MRSA) detected at four U.S. wastewater treatment plants. Environ Health Perspect 120(11):1551-1558. https://doi.org/10.1289/ehp.1205436

Saadoun I, Jaradat Z, Tayyar I, Nasser Z, Ababneh Q (2014) Airborne methicillin-resistant Staphylococcus aureus in the indoor environment of King Abdullah University Hospital, Jordan. Indoor Built Environ 24(3):315-323. https://doi.org/10.1177/ 1420326 X 14526604

Sattar S, Kibbee R, Zargar B, Wright K et al (2016) Decontamination of indoor air the risk of airborne infections: studies on survival and inactivation of airborne pathogens using an aerobiology. Am J Infect Control 44(10):177-182. https://doi.org/10.1016/j.ajic.2016.03.067

Sergelidis D, Angelidis AS (2017) Methicillin - resistant Staphylococcus aureus: a controversial food - borne pathogen. Lett Appl Microbiol 64(6):409-418. https://doi.org/10.1111/lam.12735

Sharma H, Smith D, Turner CE, Game L et al (2018) Clinical and molecular epidemiology of staphylococcal toxic shock syndrome in the United Kingdom. Emerg Infect Dis 24(2):258-266. https://doi.org/ 10.3201/eid2402.170606

Skóra J, Zduniak K, Gutarowska B, Rembisz D (2012) Harmful biological agents at museum workposts. Med Pr 63(2):153-165 (in Polish)

Smith J, Adams CE, King MF, Noakes CJ et al (2018) Is there an association between airborne and surface microbes in the critical care environment? J Hosp Infect 100(3):e123-e129. https://doi.org/10. 1016/j.jhin.2018.04.003

Sollid JU, Furberg AS, Hanssen AM, Johannessen M (2014) Staphylococcus aureus: determinants of human carriage. Infect Genet Evol 21:531-541. https://doi.org/10.1016/j.meegid.2013.03.020

Spellberg B, Guidos R, Gilbert D, Bradley J et al (2008) The epidemic of antibiotic-resistant infections: a call to action for the medical community from the Infectious Diseases Society of America. Clin Infect Dis 46(2):155-164. https://doi.org/10.1086/52489

Stryjakowska-Sekulska M, Piotraszewska-Pająk A, Szyszka A et al (2007) Microbiological quality of indoor air in university rooms. Pol J Environ Stud 4(16):623-632

Tacconelli E, Carrara E, Savoldi A, Harbarth S et al (2018) Discovery, research, and development of new antibiotics: the WHO priority list of antibiotic-resistant bacteria and tuberculosis. Lancet Infect Dis 18(3):318-327. https://doi.org/10.1016/S1473-3099(17)30753-3

Thompson JM, Gündoğdu A, Stratton HM, Katouli M (2013) Antibiotic resistant Staphylococcus aureus in hospital wastewaters and sewage treatment plants with special reference to methicillin - resistant Staphylococcus aureus (MRSA). J Appl Microbiol 114(1):44-54. https://doi.org/10.1111/jam.12037

Toro C, Janvier J, Zhang K, Fonseca K et al (2014) Communityassociated methicillin - resistant Staphylococcus aureus necrotizing pneumonia without evidence of antecedent viral upper respiratory infection. Can J Infec Microbiol 25(3):76-82

Torres O, Yeung C, Vallar E, Cabrera E (2013) Molecular identification of airborne bacteria through protein profiling in dense ground - level atmosphere. Research Congress 2013, De La Salle University Manila March 7-9

Uhrbrand K, Schultz AC, Koivisto AJ, Nielsen U, Madsen AM (2017) Assessment of airborne bacteria and noroviruses in air emission from a new highly - advanced hospital wastewater treatment plant. Water Res 112:110-119. https://doi.org/10.1016/j.watres.2017.01.046

Vantarakis A, Paparrodopoulos S, Kokkinos P, Vantarakis G et al (2016) Impact on the quality of life when living close to a municipal wastewater treatment plant. J Environ Public Health 2016:8467023. https://doi.org/10.1155/2016/8467023

Vitko NP, Richardson AR (2013) Laboratory maintenance of methicillinresistant Staphylococcus aureus (MRSA). Curr Protoc Microbiol; 0 9: Unit-9C.2. https://doi.org/10.1002/9780471729259.mc09c02s28

von Eiff C, Becker K, Machka K, Stammer H, Peters G (2001) Nasal carriage as a source of Staphylococcus aureus bacteremia. Study Group. N Engl J Med 344(1):11-16. https://doi.org/10.1056/ NEJM200101043440102

Wan M, Chou C (2014) Spreading of $\beta$ - lactam resistance gene (mecA) and methicillin - resistant Staphylococcus aureus through municipal and swine slaughterhouse wastewaters. Water Res 64:288-295. https://oi.org/10.1016/j.watres.2014.07.014

Wardyn SE, Forshey BM, Farina SA, Kates AE et al (2015) Swine farming is a risk factor for infection with and high prevalence of carriage of multidrug-resistant Staphylococcus aureus. Clin Infect Dis 61(1): 59-66. https://doi.org/10.1093/cid/civ234

Wlazło A, Górny R, Złotkowska RL, Lawniczek A et al (2008) Workers' exposure to selected biological agents in libraries of upper Silesia. Med Pr 59(2):159-170 (in Polish)

World Health Organization (2018) Global antimicrobial resistance surveillance system (GLASS) report: early implementation 2016-2017

Wu M, Feng Y, Sung W, Surampalli R (2011) Quantification and analysis of airborne bacterial characteristics in a nursing care institution. J Air Waste Manage Assoc 61(7):732-739. https://doi.org/10.3155/10473289.61.7.732

Zhong Z, Chai T, Duan H, Li X et al (2009) REP - PCR tracking of the origin and spread of airborne Staphylococcus aureus in and around chicken house. Indoor Air 19(6):511-516. https://doi.org/10.1111/j. 1600-0668.2009.00618.x

Zhou F, Wang Y (2013) Characteristics of antibiotic resistance of airborne Staphylococcus isolated from metro stations. Int J Environ Res Public Health 10(6):2412-2426. https://doi.org/10.3390/ ijerph10062412

Publisher's note Springer Nature remains neutral with regard to jurisdictional claims in published maps and institutional affiliations. 